\title{
Application of High Carbon:Nitrogen Material Enhanced the Formation of the Soil A Horizon and Nitrogen Fixation in a Tropical Agricultural Field
}

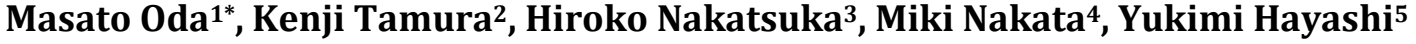 \\ ${ }^{1}$ Livestock \& Environment, Japan International Research Center for Agricultural Sciences, Tsukuba, Japan \\ ${ }^{2}$ Faculty of Life and Environmental Sciences, University of Tsukuba, Tsukuba, Japan \\ ${ }^{3}$ Graduate School of Life and Environmental Sciences, University of Tsukuba, Tsukuba, Japan \\ ${ }^{4}$ Faculty of Life and Environmental Sciences, University of Yamanashi, Yamanashi, Japan \\ ${ }^{5}$ Sitio TKM, Sao Paulo, Brazil \\ Email: ${ }^{\text {ODA.Masato@affrc.go.jp }}$
}

Received 12 August 2014; revised 18 September 2014; accepted 22 October 2014

Copyright (C) 2014 by authors and Scientific Research Publishing Inc.

This work is licensed under the Creative Commons Attribution International License (CC BY). http://creativecommons.org/licenses/by/4.0/

(c) (i) Dpen Access

\section{Abstract}

It is known that cropping causes soil carbon loss, which is a critical issue, especially in tropical agriculture. Nitrogen input generally increases net primary production but does not increase soil carbon content because nitrogen input enhances soil organic carbon mineralization by microorganisms. A farmer conducted a trial in which he applied material with a high carbon:nitrogen (C:N) ratio without additional nitrogen fertilizer, and achieved a higher productivity than that of conventional farms. Based on his results, we conducted a survey to evaluate the effects of high C:N ratio organic material on the productivity, soil profile, microbial activity, and carbon and nitrogen balance of soil. Results demonstrate that high C:N ratio organic material enhanced the formation of the soil $A$ horizon and increased soil carbon and nitrogen content. Approximately, 15 - 20 t.ha-1. crop $^{-1}$ of fresh waste mushroom bed was applied to 15 crops over 4.5 years, and the total input of carbon and nitrogen were 5014 and $129 \mathrm{~g} \cdot \mathrm{m}^{-2}$, respectively. The soil nitrate nitrogen concentration was the same as that of the neighboring forest soil, which was lower than the standard limit for conventional agriculture; however, the average productivity of crops was approximately four times that of the national average. The soil Ap horizon increased in thickness by $7 \mathrm{~cm}$, and aggregates reached a thickness of $29 \mathrm{~cm}$ in 4.5 years. The output/input ratios of total soil nitrogen and carbon were approximately $2.68-6.00$ and $1.30-2.35$, respectively, indicating that this method will maintain the carbon and nitrogen balance of the system. The observed soil microbial

"Corresponding author.

How to cite this paper: Oda, M., Tamura, K., Nakatsuka, H., Nakata, M. and Hayashi, Y. (2014) Application of High Carbon: Nitrogen Material Enhanced the Formation of the Soil A Horizon and Nitrogen Fixation in a Tropical Agricultural Field. Agricultural Sciences, 5, 1172-1181. http://dx.doi.org/10.4236/as.2014.512127 
activity was one order of magnitude higher than that of a fallow field. The results indicate that this agricultural method remediates soil degradation, and improves food production.

\title{
Keywords
}

\author{
Carbon, Food Security, Microorganisms, Nitrogen, Soil Degradation
}

\section{Introduction}

Soil carbon stocks decline by an average of $42 \%$ after land is converted from native forest to crops and by $59 \%$ after conversion of pasture to crops [1]. Soil degradation is a critical issue in tropical agriculture [2]; because, soil carbon accumulation in tropical soils is typically low [3]. In general, nitrogen input increases net primary production, but rarely increases soil carbon content [4]-[6]. Nitrogen input enhances soil organic carbon decomposition by microorganisms, therefore cropping causes a decrease in topsoil carbon content [7]. Conversely, it has been reported that differences in crop carbon inputs are positively related to soil organic carbon stock differences [8]. This information led to speculation that an input of organic material with a high carbon:nitrogen (C:N) ratio without additional nitrogen fertilization may be an effective method to increase soil carbon. However, the lower limit of available nitrate nitrogen $\left(\mathrm{NO}_{3}-\mathrm{N}\right)$ in soil is considered to be $20 \mathrm{NO}_{3}-\mathrm{N} \mathrm{mg} \cdot \mathrm{kg}^{-1}$ soil [9], [10]. The limit is the same in organic farming [11]. When organic material with a high C: $\mathrm{N}$ ratio is added to the soil, soil microorganisms use the carbon as a substrate and multiply simultaneously using the available soil nitrogen, thereby decreasing the nitrogen content of the soil [12]. To prevent this depletion, materials with a low $\mathrm{C}: \mathrm{N}$ ratio $(<20)$ are used, leading to suppression of the growth of microorganisms in the soil [13]; this is referred to as composting. As long as a high available nitrogen level is maintained in the soil, the growth of microorganisms is suppressed. Here is a contradiction.

A farmer in Brazil attempted a new farming method, adding only high C:N organic material, and he successfully obtained high productivity from many crops. The soil structure showed clear development of the soil A horizon. In this study, we evaluated the effect of this new method on the productivity, soil profile, microbial activity, and carbon and nitrogen balance of soil.

\section{Materials \& Methods}

\subsection{Study Field}

This study was carried out on a private farm owned by Mr. Tsutomu Nakamura with his cooperation. The farm is located in the city of Suzano, São Paulo, Brazil, which is located in a hilly area of Ultisols. The field had deteriorated after over 40 years of conventional farming. The application of high $\mathrm{C}: \mathrm{N}$ ratio organic material was initiated in July 2008, and by 2010 was being used on the entire 2-ha farm. The specific method was as follows: (1) the same crop was planted without a break after harvest, so that a crop was always growing; (2) approximately 15 - $20 \mathrm{t}^{\mathrm{ha}} \mathrm{h}^{-1} \cdot \mathrm{crop}^{-1}$ of fresh waste mushroom bed (C:N ratio, 39; moisture, $61.80 \%$; total carbon (T-C), 19.10\%; and total nitrogen (T-N), $0.49 \%$ ) was added to surface soil to a depth of approximately $10 \mathrm{~cm}$ using a rotary tiller; (3) no other materials (nitrogen, phosphorus, or potassium fertilizer, minerals, microelements, growth promoters, $\mathrm{pH}$ control chemicals, or agricultural chemicals) were used during the study period; (4) commercially available seedlings and seeds were used; (5) weeds were cut with a brush cutter when they began to compete with crops and were left on the fields; and (6) irrigation of crops was not conducted, except under severe drought conditions, during which irrigation was conducted the day before seeding or planting of seedlings and over the following 2 days. The fresh waste mushroom bed was transported directly from a nearby mushroom farm (Sitio TKM, Suzano) and applied immediately. The $\mathrm{NO}_{3}-\mathrm{N}$ concentration in the both $0-10 \mathrm{~cm}$ and $70-80$ $\mathrm{cm}$ of soil were $5.6 \mathrm{mg} \cdot \mathrm{kg}^{-1}$ soil (determined on Dec 12, 2010). That was the same as that of the topsoil $(0-10$ $\mathrm{cm}$ ) of the neighboring forest. Despite the low nitrogen concentration, no nitrogen deficiency or pests were observed (Figure 1). The field had no surface runoff under a rainfall rate of $50 \mathrm{~mm}$ per hour. Irrigation was not needed even when the drought period exceeded 65 days before soil survey (Nov 19, 2012). 


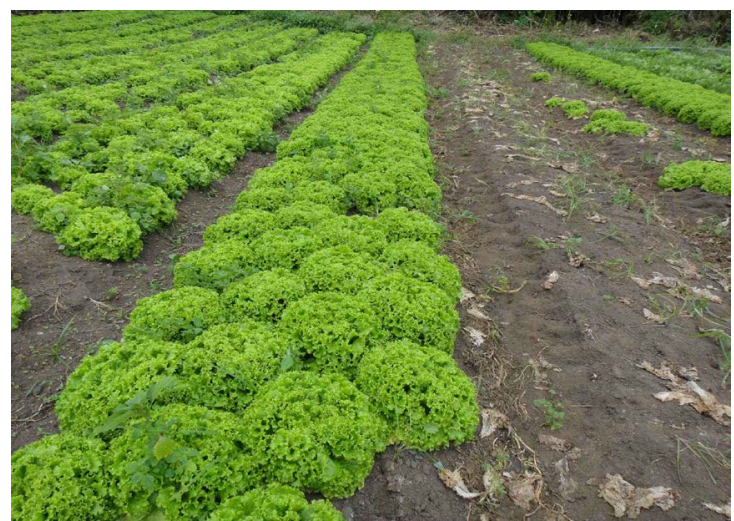

Figure 1. Lettuce in a field subject to the application of high C:N ratio organic material. Fifty-four days after planting (Nov 24, 2012) at Suzano, São Paulo, Brazil. Approximately 15 - $20 \mathrm{t} \cdot \mathrm{ha}^{-1} \cdot \mathrm{crop}^{-1}$ of fresh waste mushroom bed (C:N ratio, 39; moisture, $61.80 \%$; total carbon, $19.10 \%$; total nitrogen, $0.49 \%$ ) was added to approximately $10 \mathrm{~cm}$ of surface soil using a rotary tiller. No other materials were used. There was no irrigation, even when a drought period exceeded 65 days. No disease or insect pests were observed. Productivity achieved was four times that of the national average (Photograph taken by M. Oda).

\subsection{Productivity}

We summed the number of each vegetable harvested from 2010 to 2012 from sales records and multiplied each number by the item's standard weight. Records of each crop's area were not available; therefore, the conventional yield of the farm was calculated by weight using the top five items produced on the study field: lettuce (46\%), cabbage (23\%), napa cabbage (7\%), radish (5\%), and cauliflower (4\%). We converted the weight percentage to an area percentage, then multiplied this by the average yields. The average annual yields per ha for these crops are 21, 32, 32, 29, and $14 \mathrm{t}$, respectively [14]. For example, when the area of lettuce was $46 \%$, the area of cabbage was $15 \%(23 \% \times 21 / 32)$. The total conventional yield was $17.6 \mathrm{t}(46 \% \times 21+15 \% \times 32+4 \% \times$ $32+4 \% \times 29+6 \% \times 14)$. The total area of these top five crops was $74 \%$, so the conventional yield per ha was $23.7 \mathrm{t}(17.6 \times 100 / 74)$. This is the standard conventional yield value for Japan. The average unit yield of all vegetables in Japan is $23.3 \mathrm{t} \cdot \mathrm{ha}^{-1}$ and that of Brazil is $12.8 \mathrm{t} \cdot \mathrm{ha}^{-1}$ [15]. Thus, the conventional yield was estimated to be $13.0 \mathrm{t}(=23.7 \times 12.8 / 23.3)$.

\subsection{Soil Profiles}

We selected a top point of the study field (SF) for the soil survey, which had no water or soil inflow from the surrounding area. In the soil survey plot, lettuce (12 crops) and cabbage (2 crops) were planted from July 2008, and butter cabbages planted on April 9, 2012 were growing at the time of survey (Nov 19, 2012). We chose a neighboring farmer's field as the control field (CF). The CF was located in the same topography and was developed at the same time as the Japanese farmers' colony and implemented almost the same agricultural methods for approximately 40 years. In the CF, cassava was harvested in January 2012, and corn was grown after the addition of waste mushroom bed without fertilizer and harvested in July 2012. The CF was then kept fallow.

Soil profiles were described according to the Handbook of Soil Survey (Japanese Society of Pedology, 1997). We collected wet soil samples from each soil horizon and sieved them to $2 \mathrm{~mm}$. We took two sets of 20-mL samples: one was used for the determination of free adenosine triphosphate (ATP) and the other for the determination of moisture, and carbon and nitrogen content.

\subsection{Microbial Activity}

We decided to evaluate microbial activity rather than microbial biomass; we therefore measured free ATP, which is a measure of microbial activity. Soil samples selected by soil profiling were analyzed within 30 min. We placed samples in cups, added $50 \mathrm{~mL}$ of water, and stirred for 1 min with vibration (Power Masher, Nippi Inc, Tokyo, Japan). We then added $6 \mathrm{~mL}$ of the surface water to a sample tube and centrifuged it at $6500 \mathrm{rpm}$ 
$(2200 \times \mathrm{g})$ for $1 \mathrm{~min}$. We then placed $100 \mu \mathrm{L}$ of the solution using an autopipette into ATP Water Test Devices (Aquasnap AQ100F, Hygiena International, Camarillo, CA, USA). We measured the ATP with a luminometer (SystemSURE Plus, Hygiena International) $20 \mathrm{~s}$ after mixing in luciferase. The amount of free ATP was calculated using the weight and soil moisture of a paired sample.

\subsection{Carbon and Nitrogen Balance}

Paired soil samples were air dried. T-N and T-C concentrations of the soil samples were determined with a NC analyzer (SUMI-GRAPH NC 200F, Sumitomo Chemical, Tokyo, Japan) using the dry combustion method. The removal of nitrogen and carbon by harvested products was estimated by the average data for unit area [16]. The values per $\mathrm{m}^{2}$ were $28.4 \mathrm{~g} \mathrm{C}$ and $3.03 \mathrm{~g} \mathrm{~N}$ for lettuce and $171.6 \mathrm{~g} \mathrm{C}$ and $14.21 \mathrm{~g} \mathrm{~N}$ for cabbage (butter cabbage was considered cabbage).

The T-C and T-N balance was estimated for lower and upper limits. The lower limit was calculated from the difference between the SF and CF over the entire soil profile; this was used as the lower limit because the CF had already received one input of waste mushroom bed, and the fallow period restores soil fertility [17]. The upper limit was calculated assuming that the top three soil horizons at the SF were the same as the Bw1 horizon. The net balance was estimated by subtracting the input of components in the applied waste mushroom bed and adding removed components in harvested products to the above output.

\section{Results}

\subsection{Crop Growth and Productivity}

Thirty-three crop items were sold in the last 2 years, including leafy, fruit, and root vegetables. Lettuce and cabbage accounted for $46 \%$ and $23 \%$ of the total weight, respectively. The total annual average yield from 2010 to 2012 was $56.5 \mathrm{t} \cdot \mathrm{ha}^{-1}$, which was higher than the estimated conventional yield $\left(13.0 \mathrm{t} \cdot \mathrm{ha}^{-1}\right)$.

\subsection{Changes in Soil Structure}

The structure of the soil showed that aggregates of up to $29 \mathrm{~cm}$ formed in soil at the SF (Table 1, Figure 2). These aggregates were not earthworm feces but subangular blocky structures that formed around plant roots. In the SF, the pores of the A horizon were large, and the bulk densities of horizons Ap1 (0.68) and Ap2 (0.84) were far smaller than that of the Bw1 horizon (1.03). In the CF, the thickness of the aggregate was $22 \mathrm{~cm}$ and the bulk densities of horizons Ap1 and Ap2 were 0.90 and 0.95, respectively, which were similar to that of the Bw1 horizon (0.99).

The above differences between the two fields are related to differences in the soil carbon and nitrogen concentrations. In horizons Ap1 and Ap2, the concentrations of T-C were $76.6\left(\mathrm{mg} \cdot \mathrm{g}^{-1}\right.$ soil) and 54.1 in the SF, and

Table 1. Total carbon and total nitrogen contents of soil horizons.

\begin{tabular}{|c|c|c|c|c|c|c|c|c|c|c|c|c|c|c|c|c|}
\hline & \multirow{2}{*}{\multicolumn{2}{|c|}{ Soil horizon }} & \multirow{2}{*}{\multicolumn{2}{|c|}{$\begin{array}{l}\text { Thickness } \\
\text { (cm) }\end{array}$}} & \multirow{2}{*}{\multicolumn{2}{|c|}{$\begin{array}{l}\text { Bulk density } \\
\mathrm{Mg} \cdot \mathrm{m}^{-3}\end{array}$}} & \multicolumn{4}{|c|}{ Concentration (mg.g ${ }^{-1}$ soil) } & \multicolumn{4}{|c|}{ Amount $\left(\mathrm{g} \cdot \mathrm{m}^{-2}\right)$} & \multirow{2}{*}{\multicolumn{2}{|c|}{$\mathrm{C} / \mathrm{N}$}} \\
\hline & & & & & & & \multicolumn{2}{|c|}{ T-C } & \multicolumn{2}{|c|}{$\mathrm{T}-\mathrm{N}$} & \multicolumn{2}{|c|}{$\mathrm{T}-\mathrm{C}$} & \multicolumn{2}{|c|}{ T-N } & & \\
\hline & SF & $\mathrm{CF}$ & SF & $\mathrm{CF}$ & SF & CF & SF & $\mathrm{CF}$ & SF & $\mathrm{CF}$ & SF & $\mathrm{CF}$ & SF & $\mathrm{CF}$ & SF & $\mathrm{CF}$ \\
\hline Horizon1 & Ap1 & Ap1 & 15 & 9 & 0.68 & 0.90 & 76.6 & 27.2 & 4.66 & 2.05 & 7812 & 1665 & 475 & 166 & 16.4 & 13.3 \\
\hline Horizon2 & Ap2 & Ap2 & 14 & 13 & 0.84 & 0.95 & 54.1 & 27.1 & 3.52 & 1.99 & 6357 & 2962 & 413 & 246 & 15.4 & 13.6 \\
\hline Horizon3 & $\mathrm{AB}$ & A & 12 & 12 & 0.94 & 0.97 & 21.0 & 22.1 & 1.42 & 1.51 & 2357 & 2480 & 159 & 175 & 14.8 & 14.7 \\
\hline Horizon4 & Bw1 & Bw1 & 13 & 16 & 1.03 & 0.99 & 14.3 & 18.6 & 0.83 & 1.13 & 1919 & 3070 & 111 & 179 & 17.3 & 16.5 \\
\hline Horizon5 & Bw2 & Bw2 & 26 & 22 & 1.00 & 0.92 & 13.0 & 15.6 & 0.63 & 0.82 & 3354 & 3409 & 162 & 166 & 20.7 & 19.0 \\
\hline Horizon6 & Bw3 & Bw3 & 20 & 28 & 0.96 & 0.85 & 12.2 & 15.0 & 0.53 & 0.61 & 2337 & 4029 & 102 & 145 & 23.0 & 24.6 \\
\hline Total & - & - & 100 & 100 & - & - & - & - & - & - & 24,135 & 17,616 & 1422 & 1077 & - & - \\
\hline SF-CF & & & & & & & & & & & 65 & & & & & \\
\hline
\end{tabular}

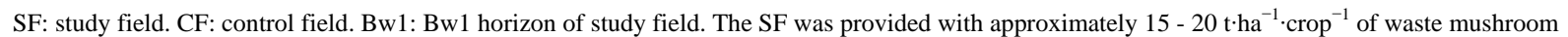
bed over 15 applications from Jul 2008 to Nov 2012. The CF was left fallow after corn harvest in July 2012. The differences in soil structure were mainly observed between horizons 1 and 2 . 

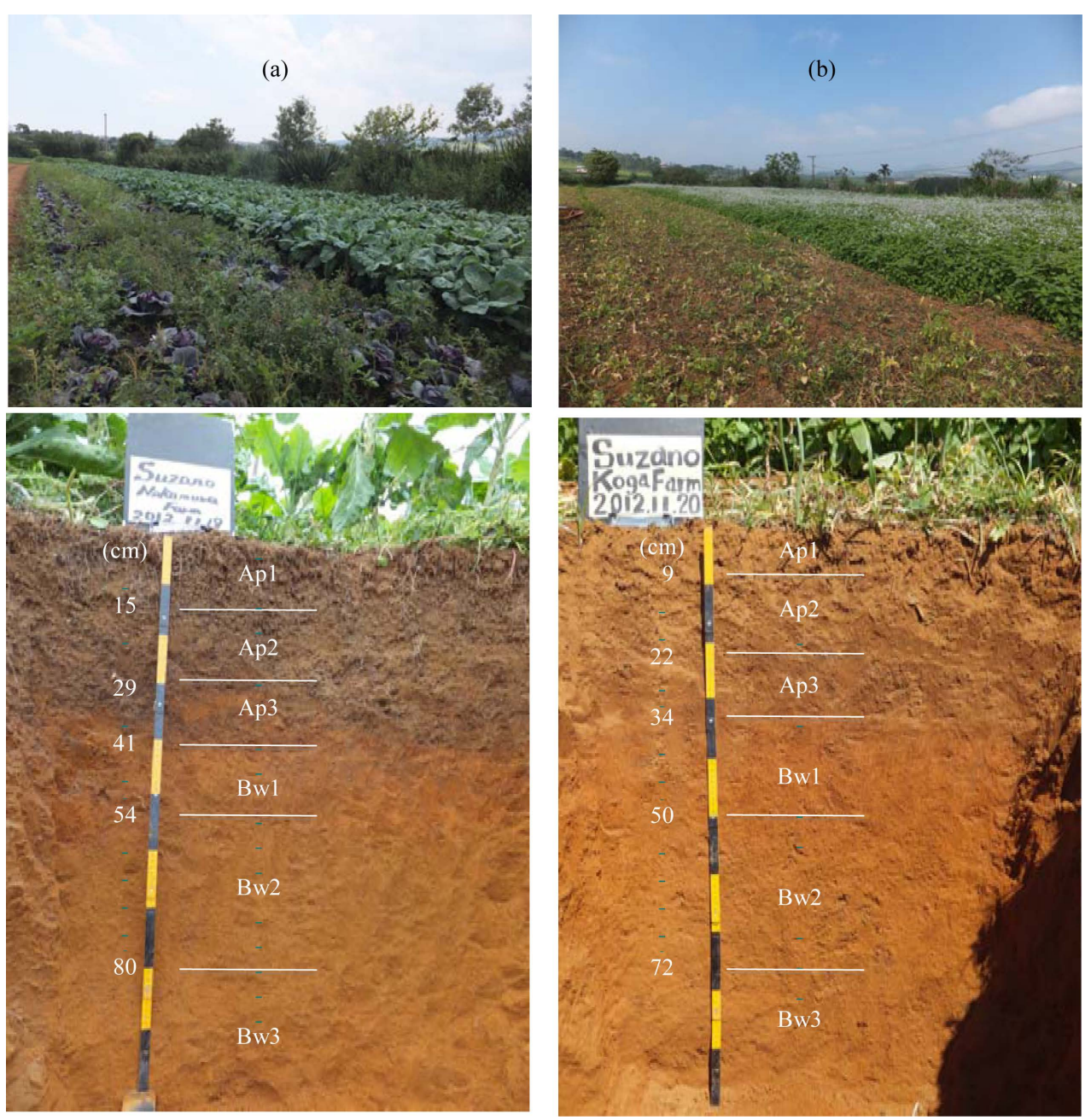

Figure 2. Landscapes and sections of the soil profile. (a) Study field (SF): Agricultural land subject to fertilization for 40 years was converted in July 2008, and 15 crops (12 lettuce crops, 2 cabbage crops, and 1 butter cabbage crop) were planted without a break after a harvest so that a crop was always growing; (b) Control field (CF): a neighboring farmer's fallow field (corn was harvested 4 months previously and cassava 10 months previously, and waste mushroom bed was used for the first time for the corn). The soil Ap horizon thickness increased by $7 \mathrm{~cm}$ and the aggregates formed up to $29 \mathrm{~cm}$ thickness in 4.5 years (Photographs taken by H. Nakatsuka).

27.2 and 27.1 in the CF, respectively. The concentrations of T-N of horizons Ap1 and Ap2 were 4.66 and 3.52 in the SF, and 2.05 and 1.99 in the CF, respectively. In both fields, concentrations of T-C and T-N in horizon 3 were 21.0 - 22.1 and $1.42-1.51$, respectively, which are much lower than the concentrations in the upper horizons. The C:N ratios of horizons 1 to 3 were 16.4, 15.4, and 14.8 at the SF and 13.3, 13.6, and 14.7 at the CF, respectively. The soil C:N ratio at the $\mathrm{CF}$ increased monotonically from the top to the bottom horizons. However, the $\mathrm{C}: \mathrm{N}$ ratio at the SF dropped at horizon 3, and the $\mathrm{C}: \mathrm{N}$ ratio of the remaining horizons were the same as those of corresponding horizons at the CF (Table 2). The gradation of the soil C:N ratio at the CF mainly reflected the decrease in T-N. The irregularity observed in horizons 1 (Ap1) and 2 (Ap2) at the SF was caused by the high soil T-C concentration.

Overall, the bulk densities of soil horizons 3 and below were similar, while the differences in soil structure were mainly observed between horizons 1 and 2 .

\subsection{Microbial Activity}

The microbial activity of soil at the SF was one order of magnitude higher than that of soil at the CF. At the SF, 
Table 2. Total carbon and nitrogen balances in soil after 15 crops.

\begin{tabular}{cccccccccc}
\hline Horizon & \multicolumn{4}{c}{ All horizons } \\
\hline Property & \multicolumn{2}{c}{$\mathrm{T}-\mathrm{C}\left(\mathrm{g} \cdot \mathrm{m}^{-2}\right)$} & \multicolumn{2}{c}{$\mathrm{T}-\mathrm{N}\left(\mathrm{g} \cdot \mathrm{m}^{-2}\right)$} & \multicolumn{2}{c}{$\mathrm{T}-\mathrm{C}\left(\mathrm{g} \cdot \mathrm{m}^{-2}\right)$} & \multicolumn{2}{c}{$\mathrm{T}-\mathrm{N}\left(\mathrm{g} \cdot \mathrm{m}^{-2}\right)$} \\
\hline Base & $\mathrm{CF}$ & $\mathrm{Bw} 1$ & $\mathrm{CF}$ & $\mathrm{Bw} 1$ & $\mathrm{CF}$ & $\mathrm{Bw} 1$ & $\mathrm{CF}$ & $\mathrm{Bw} 1$ \\
\hline Original & 17,616 & 13,137 & 1077 & 761 & 7107 & 4756 & 587 & 275 \\
SF Present & 24,135 & 24,135 & 1422 & 1422 & 16,525 & 16,525 & 1047 & 1047 \\
Output & 6520 & 10,999 & 345 & 661 & 9418 & 11,769 & 461 & 772 & 79 \\
In Products & 856 & 856 & 79 & 79 & 856 & 856 & 79 & 540 & 851 \\
Net output & 7375 & 11,854 & 424 & 740 & 10,274 & 12,625 & 540 & 129 \\
Input & 5014 & 5014 & 129 & 129 & 5014 & 5014 & 129 & 6.62 \\
Net output/input & 1.47 & 2.36 & 3.30 & 5.76 & 2.05 & 2.52 & 4.20 & 6.62 \\
Output/input & 1.30 & 2.19 & 2.68 & 5.14 & 1.88 & 2.35 & 3.58 & 6.00 \\
\hline
\end{tabular}

CF: control field. Bw1: Bw1 horizon of study field. The T-C and T-N balance was estimated for lower limit (CF base) and upper limits (Bw1 base). "SF Present" denotes the present value from the study field. "Output" denotes the difference between the SF present levels and the original levels. "Input" denotes the total amount of waste mushroom bed. The output/input ratio of soil total nitrogen and carbon were estimated to be 2.68 - 6.00 and $1.30-2.35$, respectively. Results indicate that this agricultural method allows for the maintenance of soil carbon and nitrogen.

ATP was high in the topsoil from horizons 1 to 4 (0.346, 0.125, 0.012, and $0.015 \mathrm{nmol} \cdot g \cdot$ soil $^{-1}$, respectively) and the total thickness of those horizons was $54 \mathrm{~cm}$ (Table 2 and Table 3). At the CF, ATP was also high in the topsoil from horizons 1 to $3\left(0.029,0.052\right.$, and $0.017 \mathrm{nmol} \cdot \mathrm{g} \cdot \mathrm{soil}^{-1}$, respectively) and the thickness was $34 \mathrm{~cm}$ (Table 2, Table 3). The total ATP in SF was $54.2 \mathrm{mg} \cdot \mathrm{m}^{-2}$, which was approximately five times greater than that of CF (Table 3). At the SF, 92\% of ATP was present in horizons 1 and 2 and 65\% was present only in horizon 1.

\subsection{T-C and T-N Balance}

The T-C concentration at the SF was $24,135 \mathrm{~g} \cdot \mathrm{C} \cdot \mathrm{m}^{-2}$, which was $6520 \mathrm{~g}$ higher than that at the $\mathrm{CF}$ over the entire soil profile (Table 2). At the SF, the T-C concentration in the top three soil horizons was $16,525 \mathrm{~g} \cdot \mathrm{C} \cdot \mathrm{m}^{-2}$, which was $9418 \mathrm{~g}$ higher than that of the top three horizons at the CF (Table 2). The T-C concentration in the top three horizons at the SF was $11,769 \mathrm{~g} \cdot \mathrm{C} \cdot \mathrm{m}^{-2}$ higher than the original concentration, assuming that the top three soil horizons of the SF were the same as the Bw1 horizon. In addition, the T-N content at the SF was 1422 $\mathrm{g} \cdot \mathrm{N} \cdot \mathrm{m}^{-2}$, which was $345 \mathrm{~g}$ higher than that at the CF over the entire soil profile (Table 2). In the top three soil horizons, the T-N at the SF was $1047 \mathrm{~g} \cdot \mathrm{N} \cdot \mathrm{m}^{-2}$, which was $461 \mathrm{~g}$ higher than that at the CF (Table 2). At the SF, the increase in T-N in the top three soil horizons was $722 \mathrm{~g}$, assuming that the top three soil horizons of the SF were the same as the Bw1 horizon. The balance was as follows: the input of T-C for 15 crops in 4.5 years from the waste mushroom bed was $5014 \mathrm{~g} \cdot \mathrm{m}^{-2}$, and $856 \mathrm{~g} \mathrm{C}$ was removed by harvested products. The input of T-N over the same period was $129 \mathrm{~g} \cdot \mathrm{m}^{-2}$, and $79 \mathrm{~g} \mathrm{~N}$ was removed. The net output/input (O:I) ratio of carbon was estimated to be 2.05 - 2.52 and that of nitrogen to be 4.20 - 6.62; the O:I ratios exclude harvested products were $1.88-2.35$ and $3.58-6.00$, respectively.

\section{Discussion}

\subsection{Productivity}

The productivity of the SF was four times that of the national average; nevertheless, organic farming rarely exceeds conventional farming in yield levels [18]. The $\mathrm{NO}_{3}-\mathrm{N}$ concentration in soil was $5.6 \mathrm{mg} \cdot \mathrm{kg}^{-1}$ soil, which is lower than the lower limit concentration in soil for conventional or general organic farming (20 mg $\mathrm{NO}_{3}-\mathrm{N} \mathrm{kg}^{-1}$ ) [9], [10]. The large root system and root zone are required for the absorption of a sufficient amount of nutrition under low nitrogen concentration conditions.

\subsection{Changes in Soil Characteristics}

The defining characteristic of the soil A horizon is typically the value of the bulk density. The bulk density and C:N ratio of soil horizons 3 and below were similar. Differences in soil structure were mainly observed between 
Table 3. Free ATP of the soil horizons.

\begin{tabular}{|c|c|c|c|c|c|c|}
\hline & \multicolumn{3}{|c|}{ Content } & \multicolumn{3}{|c|}{ Amount } \\
\hline & \multicolumn{3}{|c|}{$\left(\mathrm{nmol} \cdot \mathrm{g}^{-1}\right.$ soil) } & \multicolumn{3}{|c|}{$\left(\mathrm{mg} \cdot \mathrm{m}^{-2}\right)$} \\
\hline & $\mathrm{SF}$ & CF & SF/CF & $\mathrm{SF}$ & CF & SF/CF \\
\hline Horizon1 & 0.346 & 0.029 & 11.9 & 35.3 & 2.3 & 15.0 \\
\hline Horizon2 & 0.125 & 0.052 & 2.4 & 14.7 & 6.4 & 2.3 \\
\hline Horizon3 & 0.012 & 0.017 & 0.7 & 1.3 & 2.0 & 0.7 \\
\hline Horizon4 & 0.015 & 0.003 & 4.4 & 2.1 & 0.5 & 3.7 \\
\hline Horizon5 & 0.002 & 0.002 & 0.8 & 0.5 & 0.5 & 1.0 \\
\hline Horizon6 & 0.002 & 0.001 & 2.4 & 0.3 & 0.2 & 1.9 \\
\hline Total & 0.502 & 0.104 & 4.8 & 54.2 & 11.9 & 4.6 \\
\hline
\end{tabular}

SF: study field. CF: control field. Horizon: refer to Table 1. Amount of free ATP was calculated by multiplying the concentration of each soil horizon by the soil weight. The total ATP in SF was approximately five times greater than that of CF.

horizons 1 and 2. In general, agricultural activities influence carbon stock to a depth of $0.3 \mathrm{~m}$ in the profile in savanna systems [19]; we therefore focused on the top three horizons in the following discussion. At least $7 \mathrm{~cm}$ of soil A horizon was formed in 4.5 years. This is considered to be the result of an increase volume of pores because the weights of soil A horizon at the SF and CF were almost the same (332 and $321 \mathrm{~kg} \cdot \mathrm{m}^{-2}$, respectively). The increase in the ratio of the thickness of the SF soil A horizon to the CF soil A horizon was $20.6 \%$, while that of the weight was $3.4 \%$. We calculated thickness by multiplying the soil weight of SF by the bulk density of CF, when the increase in T-C contributed by carbohydrates is subtracted. The calculated thickness was $8.4 \mathrm{~cm}$ smaller than present SF thickness. This volume of soil pores can absorb approximately $80 \mathrm{~mm}$ of rainfall. This excellent soil physical property makes farming without irrigation possible [20]. It is reasonable that no surface runoff occurred under a rainfall rate of $50 \mathrm{~mm}$ per hour, or crops could grow without irrigation under the 65-day drought.

\subsection{T-C and T-N Balance and Microbial Activity}

The rate of formation of the soil A horizon described above is extraordinarily fast. The increase in soil was estimated to range from 9418 to $11,769 \mathrm{~g} \cdot \mathrm{C} \cdot \mathrm{m}^{-2}$ in response to the application of $5014 \mathrm{~g} \mathrm{C}$ by waste mushroom bed over 4.5 years. The average annual increase was $2093-2615 \mathrm{~g} \cdot \mathrm{C} \cdot \mathrm{m}^{-2} \cdot \mathrm{year}^{-1}$. Soil carbon was shown to increase in natural forests by approximately $0.2-12.0 \mathrm{~g} \cdot \mathrm{C} \cdot \mathrm{m}^{-2} \cdot \mathrm{year}^{-1}$ globally and by $2.3-2.5 \mathrm{~g} \cdot \mathrm{C} \cdot \mathrm{m}^{-2} \cdot \mathrm{year}^{-1}$ in a tropical forest [3]. Conversion of cropland to fallow land is the most effective way to increase soil organic carbon; in a meta-analysis of 39 different tropical countries, soil organic carbon increased by $6.0-11.8 \mathrm{~g} \cdot \mathrm{C} \cdot \mathrm{m}^{-2}$ in fallow lands within 7 years of conversion [6]. In the present study, the accumulation of soil carbon was drastically enhanced by the application of high $\mathrm{C}: \mathrm{N}$ ratio organic material.

The increase in soil nitrogen was estimated to range from 461 to $772 \mathrm{~g} \cdot \mathrm{N} \cdot \mathrm{m}^{-2}$ in response to the application of $129 \mathrm{~g} \mathrm{~N}$ by waste mushroom bed over 4.5 years. Including $79 \mathrm{~g} \mathrm{~N}$ that was removed from the system in the form of harvested material, the soil nitrogen increase was $91-160 \mathrm{~g} \cdot \mathrm{N} \cdot \mathrm{m}^{-2} \cdot \mathrm{g} \cdot \mathrm{year}^{-1}$. We topographically surveyed the top point of the field, which had no water or soil inflow from the surrounding area. Therefore, the increase in $\mathrm{N}$ is considered to be due to biological nitrogen fixation. This value was one order of magnitude higher than the average increase in soil nitrogen of legume crops $\left(5-33 \mathrm{~g} \cdot \mathrm{N} \cdot \mathrm{m}^{-2} \cdot \mathrm{year}^{-1}\right)$ [21]. We found that inputting high C:N ratio organic material without additional nitrogen drastically increased the soil nitrogen content.

With respect to sustainability, the SF required an input of approximately $1000 \mathrm{~g} \mathrm{~T}-\mathrm{C} \mathrm{m}^{-2} \cdot \mathrm{year}^{-1}$; however, the high productivity of SF provides considerable carbon to the soil. The current O:I ratio of carbon is greater than 1 , meaning that the SF crops are sustainable without external carbon inputs. The current O:I ratio of nitrogen is also greater than 1 .

\subsection{About the Mechanisms}

As indicated by the results of this study, productivity increased four-fold, the thickness of the soil A horizon in- 
crease by $7 \mathrm{~cm}$, and soil carbon and nitrogen accumulation were 2093 - 2615 and $91-160 \mathrm{~g} \cdot \mathrm{N} \cdot \mathrm{m}^{-2} \cdot \mathrm{g} \cdot \mathrm{year}{ }^{-1}$, respectively, over the 4.5-year study period; these are rarely observed phenomena in commercial based tropical agriculture. A similar phenomenon was observed in a method using chopped forest biomass led to carbon accumulation (1160 $\mathrm{g} \cdot \mathrm{C} \cdot \mathrm{m}^{-2} \cdot \mathrm{yr}^{-1}$ ) over a 1.5-year period following deforestation, but the effect was no longer detectable after 3 years [22]. The results were different in later years. SF was continually applied carbon, but the forest provided carbon only one time. We believe that a new concept is needed to accurately interpret the above results. For example, Hitoshi Mine, a farmer in Sao Paulo, has been by adding only organic material with a high C:N ratio (approximately 40) for 30 years in his vegetable fields; he adopted this method after observing forest ecosystems [23]. He aimed to provide carbon to microorganisms as their energy source; this is an example of indirect crop management via microorganisms. There are many types of biological nitrogen fixation systems [24]. In any case, if nitrogen fixation increases by one order of magnitude, an equivalent increase in microbial activity is required. Following the provision of carbon, the microbial activity of soil at the SF was one order of magnitude higher than that of soil at the CF. Biota is still a black box; even if we consider only fungi, the number of species globally is estimated to be 1.5 - 3 million, whereas human beings have only catalogued approximately 0.05 million species [25] [26]. Therefore, providing carbon to microorganisms as an energy source is considered a practical way to enhance the level of their activities such as nitrogen fixation. Further studies are needed to clarify the mechanisms responsible for the results observed in response to the application of organic material with a high C:N ratio.

\section{Conclusions}

1. We conducted a survey on a farm adding only high C:N ratio organic material under practical, commercial based farm management conditions.

2. The application of this material resulted in an increase in productivity, equivalent to approximately four times that of the national average in a 2-ha vegetable field. Irrigation was not needed even when the drought period exceeded 65 days.

3. Soil $\mathrm{NO}_{3}-\mathrm{N}$ concentration of the study field was $5.6 \mathrm{mg} \cdot \mathrm{kg}^{-1}$ soil, which was lower than the standard limit for conventional agriculture $\left(20 \mathrm{mg} \cdot \mathrm{kg}^{-1}\right)$; however, crop growth was vigorous and nitrogen deficiency was not observed.

4. The soil Ap horizon increased in thickness by $7 \mathrm{~cm}$ and the aggregates formed a thickness of up to $29 \mathrm{~cm}$ over 4.5 years. The amount of water that the soil pores can absorb is approximately $80 \mathrm{~mm}$ of rainfall.

5. The O:I ratio of soil T-N and T-C were estimated to be $2.68-6.00$ and $1.30-2.35$, respectively. This means that this agricultural method allows for the maintenance of the soil carbon and nitrogen balance.

6. The soil microbial activity was one order of magnitude higher than that in a control field.

7. We found that using only high $\mathrm{C}: \mathrm{N}$ ratio organic material (without additional nitrogen) drastically enhanced the formation of the soil A horizon and increased the soil carbon and nitrogen content under practical, commercial based farm management conditions.

\section{Acknowledgments}

The authors thank T. Nakamura and M. Nakamura for conducting the field experiment. We thank H. Mine, I. Nakamura, A. Fukushima, K. Toriyama, S. A. Ephraim, and J. S. Caldwell for discussion and their advice. We thank S. Nakamura and M. Yonemura for assisting in soil analysis. The authors would like to thank Edanz (http://www.edanzediting.co.jp/) for the English language review.

\section{References}

[1] Guo, L.B. and Gifford, R.M. (2002) Soil Carbon Stocks and Land Use Change: A Meta Analysis. Global Change Biology, 8, 345-360. http://dx.doi.org/10.1046/j.1354-1013.2002.00486.x

[2] Tiessen, H., Cuevas, E. and Chacon, P. (1994) The Role of Soil Organic Matter in Sustaining Soil Fertility. Nature, 371, 783-785. http://dx.doi.org/10.1038/371783a0

[3] Schlesinger, W.H. (1990) Evidence from Chronosequence Studies for a Low Carbon-Storage Potential of Soils. Nature, 348, 232-234. http://dx.doi.org/10.1038/348232a0

[4] Paustian, K., Andren, O., Clarholm, M., Hansson, A.C., Johansson, G., Lagerlof, J., Lindberg, T., Pettersson, R. and 
Sohlenius, B. (1990) Carbon and Nitrogen Budgets of Four Agro-Ecosystems with Annual and Perennial Crops, with and without N Fertilization. Journal of Applied Ecology, 27, 60-84. http://dx.doi.org/10.2307/2403568

[5] Ogle, S.M., Breidt, F.J. and Paustian, K. (2005) Agricultural Management Impacts on Soil Organic Carbon Storage under Moist and Dry Climatic Conditions of Temperate and Tropical Regions. Biogeochemistry, 72, 87-121. http://dx.doi.org/10.1007/s10533-004-0360-2

[6] Don, A., Schumacher, J. and Freibauer, A. (2011) Impact of Tropical Land-Use Change on Soil Organic Carbon Stocks-A Meta-Analysis. Global Change Biology, 17, 1658-1670. http://dx.doi.org/10.1111/j.1365-2486.2010.02336.x

[7] Lepsch, I.F., Menk, J.R.F. and Oliveira, J.B. (1994) Carbon Storage and Other Properties of Soils under Agriculture and Natural Vegetation in São Paulo State, Brazil. Soil Use and Management, 10, 34-42. http://onlinelibrary.wiley.com/doi/10.1111/j.1475-2743.1994.tb00455.x/abstract

[8] Virto, I., Barré, P., Burlot, A. and Chenu, C. (2012) Carbon Input Differences as the Main Factor Explaining the Variability in Soil Organic C Storage in No-Tilled Compared to Inversion Tilled Agrosystems. Biogeochemistry, 108, 17-26. http://dx.doi.org/10.1007/s10533-011-9600-4

[9] Fox, R.H., Roth, G.W., Iversen, K.V. and Piekielek, W.P. (1989) Soil and Tissue Nitrate Tests Compared for Predicting Soil Nitrogen Availability to Corn. Agronomy Journal, 81, 971. http://dx.doi.org/10.2134/agronj1989.00021962008100060025x

[10] Breschini, S.J. and Hartz, T.K. (2002) Presidedress Soil Nitrate Testing Reduces Nitrogen Fertilizer Use and Nitrate Leaching Hazard in Lettuce Production. HortScience, 37, 1061-1064.

[11] Entz, M.H., Guilford, R. and Gulden, R. (2001) Crop Yield and Soil Nutrient Status on 14 Organic Farms in the Eastern Portion of the Northern Great Plains. Canadian Journal of Plant Science, 81, 351-354. http://dx.doi.org/10.4141/P00-089

[12] Blair, A.W. and Prince, A.L. (1928) The Influence of Heavy Applications of Dry Organic Matter on Crop Yields and on the Nitrate Content of the Soil. Soil Science, 25, 281-288.

http://journals.lww.com/soilsci/Citation/1928/04000/THE_INFLUENCE_OF_HEAVY_APPLICATIONS_OF_DRY_ ORGANIC.4.aspx http://dx.doi.org/10.1097/00010694-192804000-00004

[13] Washington State University (n.d.) Carbon-Nitrogen Relationships. In Compost Fundamentals. http://whatcom.wsu.edu/ag/compost/fundamentals/needs_carbon_nitrogen.htm

[14] e-Stat (2013) Portal Site of Official Statistics of Japan. http://e-stat.go.jp

[15] FAOSTAT (2013) http://faostat.fao.org/

[16] Owa, N. (1996) Nutrient Balance of Crops in Japan. Environment Conservation Agriculture Research Liaison Group News, 33. http://www.niaes.affrc.go.jp/techdoc/dotoku/hozen news033.pdf

[17] Szott, L.T., Palm, C.A. and Buresh, R.J. (1999) Ecosystem Fertility and Fallow Function in the Humid and Subhumid Tropics. Agroforestry Systems, 47, 163-196. http://dx.doi.org/10.1023/A:1006215430432

[18] Seufert, V., Ramankutty, N. and Foley, J.A. (2012) Comparing the Yields of Organic and Conventional Agriculture. Nature, 485, 229-232. http://dx.doi.org/10.1038/nature11069

[19] Pringle, M.J., Allen, D.E., Dalal, R.C., Payne, J.E., Mayer, D.G., O’Reagain, P. and Marchant, B.P. (2011) Soil Carbon Stock in the Tropical Rangelands of Australia: Effects of Soil Type and Grazing Pressure, and Determination of Sampling Requirement. Geoderma, 167-168, 261-273. http://dx.doi.org/10.1016/j.geoderma.2011.09.001

[20] Parikh, S.J. and James, B.R. (2012) Soil: The Foundation of Agriculture. Nature Education Knowledge, 3, 2. http://www.nature.com/scitable/knowledge/library/soil-the-foundation-of-agriculture-84224268

[21] Montañez, A. (2000) Overview and Case Studies on Biological Nitrogen Fixation: Perspectives and Limitations. Science in Agriculture, 1-11. http://www.fao.org/fileadmin/templates/agphome/scpi/SCPI_Compendium/Overview_and_Case_studies_on_Biologica l_Nitrogen_Fixation.pdf

[22] Perrin, A.S., Fujisaki, K., Petitjean, C., Sarrazin, M., Godet, M., Garric, B., Horth, J.C., Balbino, L.C., Filho, A.S., de Almeida Machado, P.L.O., et al. (2014) Conversion of Forest to Agriculture in Amazonia with the Chop-and-Mulch Method: Does It Improve the Soil Carbon Stock? Agriculture, Ecosystems \& Environment, 184, 101-114. http://dx.doi.org/10.1016/j.agee.2013.11.009

[23] Hayashi, Y. (2004) Practices of “Tansojunkan noho”. Gendai-Nogyo, 10, 112-118.

[24] Wagner, S.C. (2011) Biological Nitrogen Fixation. Nature Education Knowledge, 3, 15. http://www.nature.com/scitable/knowledge/library/biological-nitrogen-fixation-23570419

[25] Hawksworth, D.L. (2001) The Magnitude of Fungal Diversity: The 1.5 Million Species Estimate Revisited. Mycologi- 
cal Research, 105, 1422-1432. http://dx.doi.org/10.1017/S0953756201004725

[26] Hawksworth, D.L. (2012) Global Species Numbers of Fungi: Are Tropical Studies and Molecular Approaches Contributing to a More Robust Estimate? Biodiversity and Conservation, 21, 2425-2433.

http://dx.doi.org/10.1007/s10531-012-0335-X 
Scientific Research Publishing (SCIRP) is one of the largest Open Access journal publishers. It is currently publishing more than 200 open access, online, peer-reviewed journals covering a wide range of academic disciplines. SCIRP serves the worldwide academic communities and contributes to the progress and application of science with its publication.

Other selected journals from SCIRP are listed as below. Submit your manuscript to us via either submit@scirp.org or Online Submission Portal.
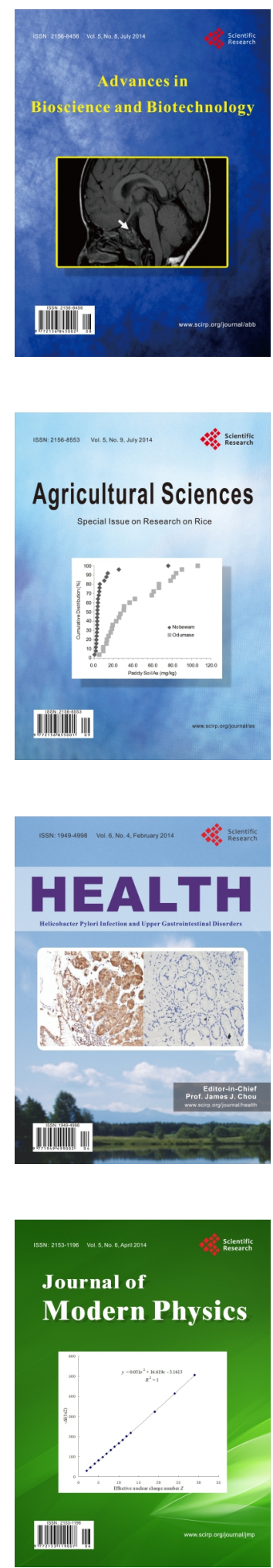
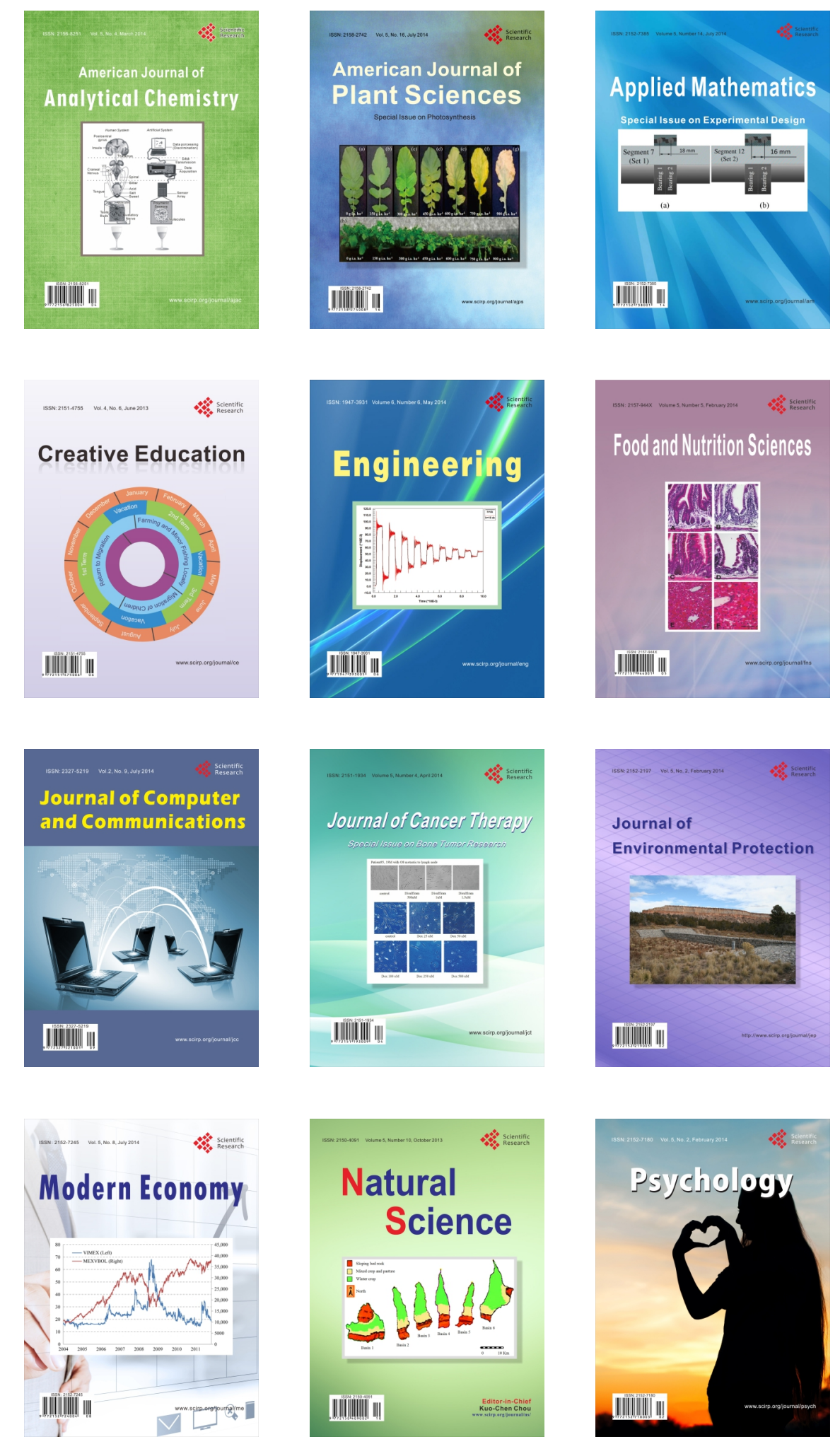